\title{
PROBLEMATIKA PASCA DI TERAPKAN PERATURAN BUPATI NOMOR 2 TAHUN 2020 BADAN AMIL ZAKAT NASIONAL (BAZNAS) KABUPATEN BENGKALIS
}

\author{
Fiza Hariani ${ }^{1}$, Husni Thamrin ${ }^{2}$, Yuliana ${ }^{3}$, Jufendri ${ }^{4}$, Mhd Reynaldei ${ }^{5}$, \& Muhammad \\ Dasio $^{6}$ \\ 1,2,3,4,5 \& 6 Prodi Ekonomi Syari'ah, Pascasarjana UIN Sultan Syarif Kasim Riau \\ Email:22190324827@students.uin-suska.ac.id,husni2017husni@gmail.com, \\ 22190314701@students.uin-suska.ac.id,22190314571@students.uin-suska.ac.id, \\ 22190314569@students.uin-suska.ac.id,22190314513@students.uin-suska.ac.id,
}

\begin{abstract}
ABSTRAK
Penelitian ini dilakukan untuk mengetahui problematika pasca diterapkan Peraturan Bupati Nomor 2 Tahun 2020 Baznas Kabupaten Bengkalis tentang Petunjuk Teknis Pelaksana Peraturan Daerah Kabupaten Bengkalis Nomor : 3 Tahun 2018. Penelitian ini menggunakan analisis rasio penelitian Ritchie \& Kolodinsky untuk organisasi nirlaba. Objek yang digunakan dalam penelitian ini adalah Laporan Laporan Keuangan Badan Amil Zakat Nasional (BAZNAS) Kabupaten Bengkalis selama rentang periode 2018 sampai dengan 2020. Hasil penelitian dengan menggunakan rasio penelitian Ritchie \& Kolodinsky yakni Rasio Kinerja Fiskal (Fiscal Performance), Rasio Dukungan Publik (Public Support) dan Rasio Efisiensi Penghimpunan Dana (Fundraising Efficiency) ini menunjukkan bahwa kinerja keuangan BAZNAS Kabupaten Bengkalis selama 3 (tiga) tahun terakhir dinyatakan seluruhnya Baik.
\end{abstract}

Kata Kunci : BAZNAS, Kinerja Keuangan, Laporan Keuangan.

\begin{abstract}
This study aims to assess Problems after applied Bengkalis Regent's Regulation Number : 2 of 2020 BAZNAS in Bengkalis about Implementing Technical Instruction Bengkalis Regency Regulation Number : 3 of 2018. This study by using financial performance measurement ratio model from Ritchie $\&$ Kolodinsky research for non profit organization. The object used in this research is financial report of National Amil Zakkah Agency (BAZNAS) in Bengkalis Regency for 3 years during period 2018 to 2020. The components of the ratio model from Ritchie \& Kolodinsky research used are Fiscal Performance Ratio, Public Support Ratio and Fundrising Efficiency Ratio, financial performance over the last 3 years ago well Expressed.
\end{abstract}

Keywords :BAZNAS, Financial Performance, Financial Statement. 


\section{PENDAHULUAN}

Pengelolaan Zakat di Indonesia telah diatur oleh Pemerintah Republik Indonesia melalui Undang-Undang Nomor : 23 Tahun 2011 tentang Pengelolaan Zakat yang menggantikan Undang-Undang Nomor 38 Tahun 1999. Adapun pelaksanaan Undangundang tersebut telah ditetapkan oleh Pemerintah melalui Peraturan Pemerintah Nomor 14 Tahun 2014 tentang Pelaksanaan UU 23 tahun 2011 tentang Pengelolaan Zakat. Dalam Peraturan Pemerintah dimaksud, Pengelolaan zakat adalah kegiatan perencanaan, pelaksanaan, dan pengoordinasian dalam pengumpulan, pendistribusian, dan pendayagunaan zakat.

Berdasarkan Undang-Undang Nomor : 23 Tahun 2011 Badan Amil Zakat Nasional yang selanjutnya disingkat BAZNAS adalah lembaga yang berwenang melakukan pengelolaan zakat secara nasional. Dalam rangka pengelolaan Zakat, Infak dan Sedekah, BAZNAS dibantu oleh Lembaga Amil Zakat (LAZ) yang membantu pengumpulan, pendistribusian, dan pendayagunaan zakat pada tingkat kabupaten/kota seperti salah satunya BAZNAS Kabupaten Bengkalis. Dalam hal ini BAZNAS Kabupaten Bengkalis adalah badan amil zakat yang dibentuk oleh Menteri atau Pejabat yang ditunjuk atas usul Bupati setelah/mendapat pertimbangan BAZNAS. BAZNAS dalam hal ini memiliki kewajiban untuk mendistribusikan Zakat, Infak dan Sedekah kepada Mustahik sesuai dengan syariat Islam.

Dalam melakukan pengelolaan zakat, BAZNAS Kabupaten Bengkalis telah diatur melalui Peraturan Daerah Kabupaten Bengkalis Nomor : 3 Tahun 2018 tentang Pengelolaan Zakat, Infak dan Sedekah yang diterbitkan pada tanggal 5 September Tahun 2018. Perda ini ditetapkan oleh Pemerintah Kabupaten Bengkalis menimbang bahwa pengelolaan zakat merupakan pengelolaan dana umat Islam yang harus dilaksanakan sesuai syariah, profesional, amanah dan transparan dengan program kerja yang jelas dan terarah.
Berdasarkan Catatan Atas Laporan Keuangan BAZNAS Kabupaten Bengkalis, Sejak mulai diberlakukannya Peraturan Daerah Kabupaten Bengkalis dan Peraturan Bupati Bengkalis tentang Zakat dimaksud, total Muzakki di Pemerintah Daerah Kabupaten Bengkalis mengalami kenaikan dari tahun-tahun sebelumnya dengan rincian total Muzakki Tahun 2018 berjumlah 1.320 orang, Tahun 2019 berjumlah 1.405 orang dan untuk Tahun 2020 mengalami kenaikan jumlah Muzakki berjumlah 1.711 orang. Total Muzakki tersebut diantaranya adalah para Aparatur Sipil Negara/PNS yang mengabdi pada Pemerintah Daerah Kabupaten Bengkalis. Selain itu sejak diberlakukannya PERDA dan PERBUP tersebut, belum semua Organisasi Perangkat Daerah di lingkup Pemerintah Kabupaten Bengkalis yang menjadi Muzakki yang membayar Zakat di BAZNAS Kabupaten Bengkalis.

\section{TINJAUAN PUSTAKA}

\section{Pengertian Zakat}

Secara bahasa, zakat berarti tumbuh (nummuw) dan bertambah (zidayah). Jika diucapkan, zaka al-zar artinya adalah tanaman itu tumbuh dan bertambah. Jika diucapkan zakat alnafaqah, artinya nafkah tumbuh dan bertambah jika diberkati. Adapun zakat menurut syara', berarti hak yang wajib (dikeluarkan dari harta). (AlZuhaily, 1995)

Dalam terminologi bahasa, kata zakat merupakan kata dasar (masdar) dari zaka yang berarti berkah, tumbuh, bersih, dan baik. Sesuatu itu zaka, berarti tumbuh dan berkembang, dan seorang itu zaka, berarti orang itu baik. Tetapi yang terkuat, menurut wahidi dan lain-lain, kata dasar zaka berarti bertambah dan tumbuh, sehingga bisa dikatakan, tanaman itu zaka, artinya tumbuh, sedangkan tiap sesuatu yang bertambah disebut zaka artinya bertambah. Bila satu tanaman tumbuh tanpa cacat, maka kata zaka disini berarti bersih. Dan bila seseorang diberi sifat zaka dalam arti baik, maka berarti orang itu lebih banyak mempunyai sifat yang 
baik. Seorang itu zaki, berarti seorang yang memiliki lebih banyak sifat-sifat orang baik, dan kalimat "hakim-zaka-saksi" berarti hakim mengatakan jumlah saksi-saksi diperbanyak. (Qardhawi, 2010)

Menurut Hafidhudin (1998), ditinjau dari segi bahasa zakat mempunyai beberapa arti, yaitu Al- Baraktu "keberkahan", AlNamaa "pertumbuhan dan perkembangan," Ath Thaharatu, kesucian, dan Ash Shalahu "keberesan". Sedangkan secara istilah yaitu bahwa zakat adalah bagian dari harta dengan persyaratan tertentu yang Allah SWT mewajibkan kepada pemiliknya untuk diserahkan kepada yang berhak menerimanya dengan persyaratan tertentu pula.

Secara bahasa kata zakat mempunyai arti, yaitu : keberkahan, pertumbuhan, perkembangan, dan kesucian, secara istilah zakat adalah bagian dari harta dengan persyaratan tertentu yang diwajibkan Allah SWT kepada pemiliknya untuk diserahkan kepada yang berhak menerimanya dengan persyaratan tertentu pula. Dengan demikian pengertian zakat baik secara bahasa dan istilah bahwa harta yang dikeluarkan zakatnya akan menjadi berkah, tumbuh, berkembang dan bertambah, suci dan baik (Prasetyoningrum, 2015).

Makna keberkahan yang terdapat pada zakat berarti dengan membayar zakat akan memberikan berkah kepada harta yang dimiliki. Zakat berarti pertumbuhan karena dengan memberikan hak fakir miskin dan lain-lain yang terdapat dalam harta benda kita, akan terjadilah suatu sirkulasi uang yang dalam masyarakat mengakibatkan berkembangnya fungsi uang itu dalam kehidupan perekonomian di masyarakat. Zakat bermakna kesucian ataupun keberesan yang dimaksudkan untuk membersihkan harta benda milik orang lain, yang dengan sengaja atau tidak sengaja, termasuk ke dalam harta benda kita (Nasrullah, 2010)

Zakat bertujuan untuk mengatasi kesenjangan sosial antara si kaya dengan si miskin. Selain itu, zakat juga dapat mempererat hubungan antara manusia dengan sang Pencipta melindungi kekayaan itu dari kebinasaan.

Ibadah zakat tidak hanya sebagai ibadah pribadi sebagai tanda kesalehan dan kepatuhan kepada Allah SWT, namun zakat juga memiliki dampak sosial yang signifikan sebagai distribusi kekayaan dan sebagai realisasi dari konsep keadilan sosio ekonomi yang ada di dalam ajaran Islam. Zakat merupakan ibadah maaliyah ijtima'iyyah yang memiliki posisi yang sangat penting dan strategis dari sisi ajaran Islam dan pembangunan kesejahteraan ekonomi umat Islam. (Sakti, 2007)

Zakat mengandung hikmah dan manfaat yang demikian besar dan mulia, baik yang berkaitan dengan orang yang berzakat (Muzakki), penerimanya (Mustahik), harta yang di keluarkan zakatnya, maupun bagi masyarakat keseluruhan. (Qadir, 1998)

\section{Laporan Keuangan Lembaga Amil Zakat}

Penyajian Laporan Keuangan oleh Lembaga Amil Zakat seperti BAZNAS merupakan suatu kewajiban seperti yang telah diamanatkan dalam Undang-Undang Nomor : 23 Tahun 2011 tentang Pengelolaan Zakat. Sesuai dengan Undang-undang tersebut menjadi suatu keharusan BAZNAS melaporkan hasil pelaksanaan tugasnya secara tertulis kepada Presiden melalui Menteri dan kepada Dewan Perwakilan Rakyat Republik Indonesia paling sedikit 1 (satu) kali dalam 1 (satu) tahun.

Adapun komponen Laporan Keuangan Organisasi Pengelola Zakat (OPZ) diantaranya adalah :

a. Laporan posisi keuangan (Neraca) Terdiri dari tiga unsur yaitu Asset, Liabilitas, dan Saldo Dana.

b. Laporan perubahan dana menggambarkan kinerja dana yang dikelola yaitu penerimaan dan penyaluran dana zakat, dana infak/sedekah, dana amil, dan dana lainnya. 
c. Laporan perubahan aset kelolaan menggambarkan perubahaan aset zakat dan aset infak/sedekah yang dikelola oleh lembaga zakat.

d. Laporan arus kas laporan yang menunjukkan penerimaan dan pengeluaran kas lembaga selama periode tertentu yang dikelompokkan dalam aktivitas operasi, investasi dan pendanaan.

Catatan atas laporan keuangan merupakan informasi tambahan atas apa yang disajikan dalam laporan posisi keuangan, laporan perubahan dana, laporan perubahan aset kelolaan, dan laporan arus kas.

\section{Pengukuran Kinerja Organisasi Pengelola Zakat}

Pengukuran kinerja keuangan dapat dilakukan untuk lembaga zakat sebagaimana yang dilakukan terhadap lembaga nirlaba. Hal ini dikarenakan lembaga zakat merupakan bagian dari organisasi nirlaba pemerintah yang tidak berorientasi terhadap laba. Pengukuran kinerja keuangan lembaga zakat telah dilakukan dalam beberapa penelitian dengan menggunakan beberapa pendekatan yang berbeda, salah satunya menggunakan analisis rasio keuangan yang relevan untuk diterapkan. Beberapa diantaranya adalah rasio yang terdapat pada fiscal performance, public support, fundrising efficiency. (Ritchie \& Kolodinsky, 2013).

\section{a. Fiscal Performance}

Rasio Kinerja Fiskal dapat dihitung dengan menggunakan rumus :

a) Total Pendapatan dibagi Total Aset (TR : TA) ;

b) (Total Pendapatan dikurangi Total Biaya) dibagi dengan total aset ; (TR-TE)/TA

\section{Ket :}

Total Revenue (TR)

Seluruh total penerimaan dana
Total Assets (TA) : Seluruh total aset yang dimiliki OPZ

Total Expense (TE) : $\quad$ Seluruh biaya atau penggunaan dana.

\section{b. Public Support}

Komponen rasio ini adalah :

a) Total Kontribusi dibagi Total Pendapatan (TC/TR)

b) Total Kontribusi dibagi dengan Total Biaya (TC/TE)

\section{Ket :}

Total Contribution (TC) : Total penerimaan dari dana sukarela

\section{c. Fundrising Efficiency}

Dihitung dengan menggunakan rumus (TR/FE)

\section{Ket :}

Fundrising Expenses (FE):Total biaya penghimpunan dana

\section{Legalitas Penghimpunan Zakat}

Peraturan Daerah Kabupaten Bengkalis Nomor : 3 Tahun 2018 tentang Pengelolaan Zakat, Infak dan Sedekah diterbitkan di Bengkalis tepatnya pada tanggal 5 September Tahun 2018 oleh Bupati Bengkalis dan diundangkan pada tanggal 6 September Tahun 2018 oleh Sekretaris Daerah Kabupaten Bengkalis.

Menindaklanjuti Peraturan Daerah Kabupaten Bengkalis Nomor : 3 Tahun 2018 tentang Pengelolaan Zakat, Infak dan Sedekah, Pemerintah Kabupaten Bengkalis juga telah menetapkan Peraturan Bupati Bengkalis Nomor : 2 Tahun 2020 tentang Petunjuk Teknis Pelaksana Perda tersebut. Perbup ini ditetapkan pada tanggal 6 Januari Tahun 2020 dan mulai berlaku pada tanggal diundangkan yakni 7 Januari Tahun 2020.

\section{Penelitian Terdahulu}

Pertama, penelitian dengan judul Analisis Kinerja Keuangan Lembaga Zakat (Studi Kasus : Badan Amil Zakat Nasional). Penelitian ini bertujuan untuk menilai kinerja 
keuangan lembaga zakat dengan menggunakan model 5 (lima) rasio pengukuran kinerja keuangan dari Ritchi \& Kolodinsky untuk organisasi nirlaba dengan objek penelitian berupa laporan keuangan BAZNAS selama rentang periode 2004 sampai dengan 2013. Rasio yang digunakan adalah Rasio Knerja Fiskal (Fiscal Performance), Rasio Dukungan Publik (Public Support) dan Rasio Efisiensi Penghimpunan Dana (Fundrising Efficiency). Hasil penelitiannya adalah kelima rasio yang diteliti menunjukkan kinerja keuangan BAZNAS selama sepuluh tahun terakhir dinyatakan baik. (Romantin et al, 2017)

Kedua, penelitian dengan judul Komparasi Kinerja Keuangan Lembaga Amil Zakat. Penelitian ini menganalisis data laporan keuangan 4 (empat) lembaga zakat nasional yang memenuhi kriteria sampel yang terdiri dari BAZNAS Pusat 3 (tiga) LAZNAS. Penelitian ini menggunakan rasio keuangan yang terdapat dalam Indonesian Standard of Zakat Management (ISZM) yang terdiri dari Rasio Efisiensi dan Rasio Kapasitas. Hasil penelitian menunjukkan bahwa secara umum kinerja keuangan BAZNAS Pusat dan 3 (tiga) LAZNAS selama kurun waktu penelitian (2014-2016) dapat dikatakan baik. (P. Harto et al, 2018)

Ketiga, penelitian tentang Analisis Kinerja Lembaga Amil Zakit Pada Badan Amil Zakat Nasional (BAZNAS) Kabupaten Ogan Hilir dengan Metode Indonesia Magnificence Zakat (IMZ). Penelitian ini menggunakan pengukuran kinerja yang terdiri dari Kinerja Kepatuhan Syariah, Kinerja Manajemen, Kinerj Keuangan, Kinerja Program Pendayagunaan, dan Kinerja Legitimasi Sosial. Hasil penelitian menunjukkan bahwa secara umum kinerja BAZNAS selama rentang waktu Tahun 2014 sampai dengan 2018 dengan metode IMZ adalah cukup baik dimana mengalami peningkatan dari tahun-tahun sebelumnya. (Ardani et al, 2019)

Keempat, penelitian tentang Efektivitas Kinerja Keuangan Badan Amil
Zakat Nasional (BAZNAS) Pada Program Pentasharufan dana Zakat di BAZNAS Kota Yogyakarta. Tujuan dari penelitian ini adalah untuk mengetahui kinerja efisiensi BAZNAS Yogyakarta dalam menghimpun dan menyalurkan dana zakat dari Muzakki kepada Mustahik. Adapun metode analisa yang digunakan adalah Metode Allocation to Collection Ratio (ACR) dengan membandingkan laporan keuangan untuk beberapa periode. Hasil penelitian menunjukkan bahwa tingkat efisiensi penyaluran zakat Tahun 2012 menunjukkan kategori fairly effective, Tahun 2013 dan 2014 dengan kateogori effective, Tahun 2015 menunjukkan kategori highly effective dan Tahun 2016 dengan kategori fairly effective. (Azizah, 2018)

Kelima, penelitian yang berjudul Penilaian Kinerja Lembaga Amil Zakat dengan pendekatan Indonesia Magnificence Zakat (IMZ). Penelitian kualitatif dengan metode evaluasi ini bertujuan untuk menganalisis kinerja Lembaga Amil Zakat YDSF Cabang Jember selama Tahun 20122014 dengan menggunakan standar penilaian berdasarkan buku Indonesia Zakat and Development Report 2011 (IZDR). Hasil penelitian terhadap lima komponen yaitu Kinerja Kepatuhan Syariah, Legalitas, dan Kelembagaan, Kinerja Manajemen, Kinerja Keuangan, Kinerja Program Pendayagunaan, dan Kinerja Legitimasi Sosial, menunjukkan bahwa kinerja YDSF Cabang Jember tidak mengalami peningkatan maupun penurunan kinerja selama Tahun 2012-2014. (Yuanita, 2016)

\section{METODE PENELITIAN}

Penelitian pada ini menggunakan jenis penelitian lapangan (field research), yaitu memaparkan dan menggambarkan keadaan serta fenomena yang lebih jelas mengenai situasi yang terjadi (Leksono, 2013) dan yang dijadikan sebagai data primer pada penelitian ini yaitu data yang secara langsung diperoleh dari objek penelitian seperti Struktur Organisasi/Gambaran Umum Badan Amil Zakat Nasional (BAZNAS) Kabupaten 
Bengkalis dan Peraturan Daerah Kabupaten Bengkalis Nomor : 03 Tahun 2018 tentang tentang Pengelolaan Zakat, Infaq dan Sedekah. Data sekunder yang digunakan dalam penelitian ini adalah berupa data yang sudah jadi berupa Laporan Keuangan Badan Amil Zakat Nasional (BAZNAS) Kabupaten Bengkalis selama 3 (tiga) Tahun Anggaran yakni 2018 sampai dengan 2020. Dan di analisis dengan metode deskriptif yang mengkaji problematika pasca diterapkannya Peraturan Bupati Nomor 02 Tahun 2020.

\section{HASIL DAN PEMBAHASAN}

Berdasarkan Catatan Atas Laporan Keuangan BAZNAS Kabupaten Bengkalis, sejak mulai diberlakukannya Peraturan Daerah Kabupaten Bengkalis Nomor : 3 Tahun 2018 tentang Pengelolaan Zakat, Infak dan Sedekah dan Peraturan Bupati Bengkalis Nomor : 2 Tahun 2020 tentang Petunjuk Teknis Pelaksana Perda tersebut, total Muzakki di Pemerintah Daerah Kabupaten Bengkalis mengalami kenaikan dari tahun-tahun sebelumnya. Total Muzakki Tahun 2018 berjumlah 1.320 orang, Tahun 2019 berjumlah 1.405 orang dan untuk Tahun 2020 mengalami kenaikan jumlah Muzakki berjumlah 1.711 orang. Total Muzakki tersebut diantaranya adalah para Aparatur Sipil Negara/PNS yang mengabdi pada Pemerintah Daerah Kabupaten Bengkalis. Disamping itu sejak diberlakukannya PERDA dan PERBUP tersebut, belum semua Organisasi Perangkat Daerah di lingkup Pemerintah Kabupaten Bengkalis yang menjadi Muzakki yang membayar Zakat di BAZNAS Kabupaten Bengkalis.

\section{Fiscal Performance BAZNAS Kabupaten Bengkalis}

Rasio ini menggunakan data Total Revenue/TR (perolehan dana) dan Total Asset (TA). Adapun data Total Revenue/TR (perolehan dana) pada BAZNAS Kab. Bengkalis disajikan pada gambar dibawah ini.

\section{Gambar 1. Total Perolehan Dana dan Total Asset BAZNAS Kab. Bengkalis (dalam Milyar Rupiah)}

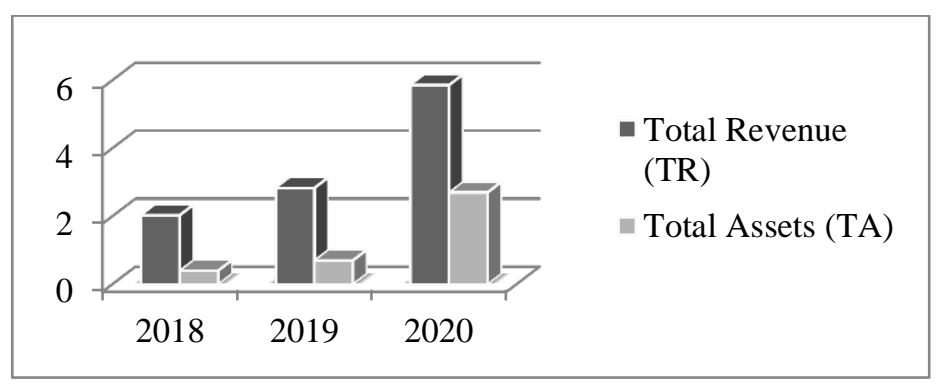

Sumber : Laporan Keuangan BAZNAS Kab. Bengkalis (2020)

Perolehan dana (Total Revenue) tertinggi pada BAZNAS Kab. Bengkalis tahun 2020 Rp. 5.862.002.722,00. Angka pencapaian ini mengalami kenaikan sebesar 106,76\% dari Tahun 2019 dan 39,18\% dari Tahun 2018. Total Assets (TA) tahun 2020 yakni mencapai Rp. 2.696.581.067,00. Aset yang berhasil diperoleh terdiri dari Aset Lancar dan Aset Tidak Lancar. Angka pencapaian ini mengalami kenaikan sebesar 284,15\% dari Tahun 2019 dan 75,04\% dari Tahun 2018. Berdasarkan Laporan Posisi Keuangan BAZNAS Kab. Bengkalis bahwa
Total Assets (TA) didominasi oleh Aset Lancar berupa Kas dan Setara Kas yang memberikan porsi lebih dari $90 \%$ dari keseluruhan Total Assets (TA). Sementara porsi Aset Tidak Lancar yang berupa Aset Tetap hanya memberikan kontribusi dibawah 10\% dari Total Assets (TA).

Total penyaluran dana zakat tertinggi pada BAZNAS Kab. Bengkalis adalah pada Tahun $2020 \quad$ Rp. $3.008 .137 .947,00$ mengalami kenaikan sebesar $77,55 \%$ dari Tahun 2019. Total penyaluran dana Infaq dan sedekah tertinggi juga pada Tahun 2020 
yakni mencapai Rp. 211.098.036,00 atau $308,55 \%$ dari Tahun 2019. Berbeda halnya dengan total penggunaan dana yang bersumber dari Beban Manajemen dan

\section{Gambar 2. Total Expense (TE) BAZNAS Kab. Bengkalis (dalam Milyar Rupiah)}

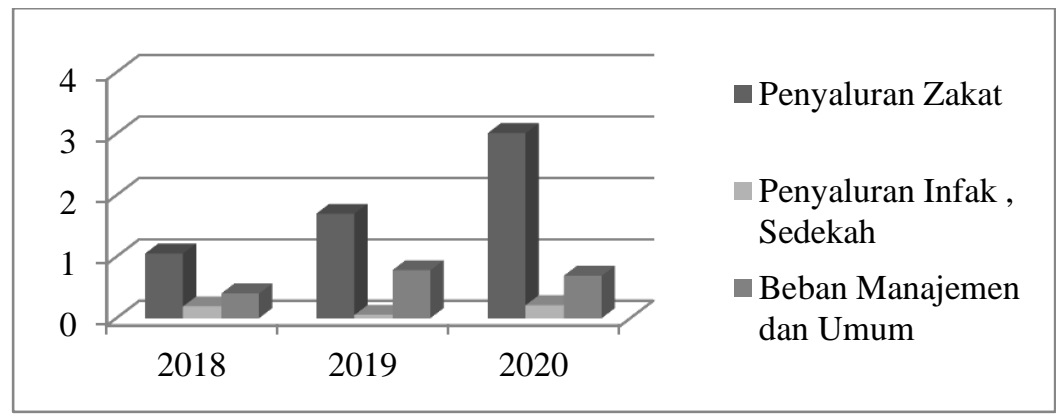

Sumber : Laporan Keuangan BAZNAS Kab. Bengkalis(2020)

Fiscal Performance rata-rata 3,76 (diatas 1 point) menunjukkan bahwa BAZNAS Kab. Bengkalis masuk dalam kategori memiliki pendapatan tahunan lebih besar dari total asetnya. Adapun hasil perhitungan rasio ini selama 3 (tiga) tahun terakhir rasio ini menunjukkan hasil yang positif walaupun dengan kondisi fluktuatif. Rata-rata rasio ini berada di posisi angka 0,70. Rasio yang bernilai positif ini menunjukkan bahwa organisasi memiliki pendapatan yang lebih besar dari biaya dan dengan proporsi pendapatan yang dapat

Gambar 3. Total Penghimpunan Dana Dukungan Publik dan Dana Sukarela BAZNAS Kab. Bengkalis (dalam Milyar Rupiah)

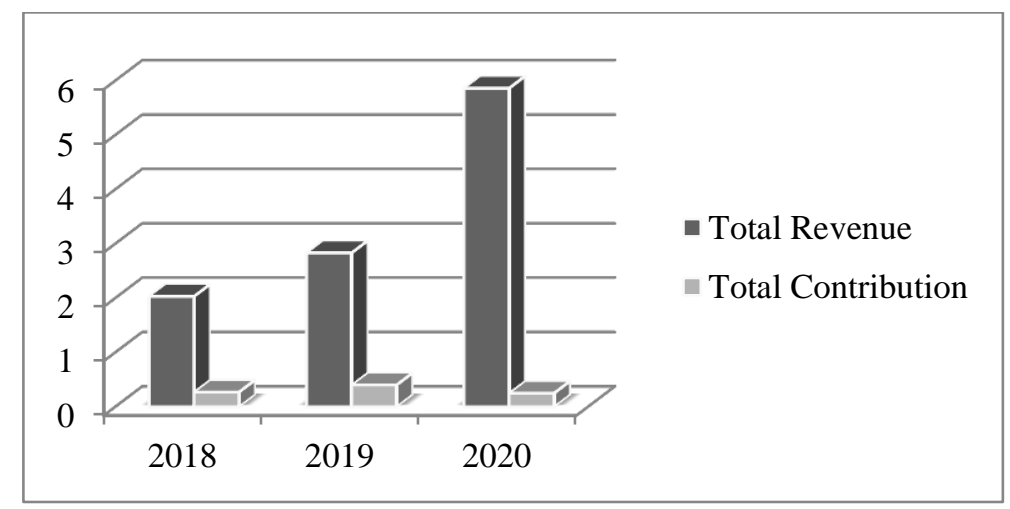

Sumber : Laporan Keuangan BAZNAS Kab. Bengkalis (2020)

Perolehan dana pada BAZNAS Kab. Bengkalis terdiri dari dua sumber yakni total contribution yang bersumber dari APBD/N sebesar 14\% untuk Tahun 2018, 14\% untuk Tahun 2019 dan 4\% untuk Tahun 2020 dari disimpan menjadi aset pada tahun tersebut. Hal ini berarti bahwa kondisi keuangan BAZNAS Kab. Bengkalis masuk dalam kategori baik dimana pendapatan (perolehan dana) lebih besar daripada biaya (penggunaan dana).

\section{Public Support BAZNAS Kabupaten Bengkalis}

Rasio ini menggunakan data Total Contribution/TC dan Total Revenue (TR) yang dapat dilihat pada Gambar berikut. 
dan terendah diterima justru di Tahun 2020 sebesar Rp. 250.000.000,00. Sedangkan pada Tahun 2018 BAZNAS Kab. Bengkalis tidak hanya menerima dana APBD/N sebesar Rp. 250.000.000,00, tetapi juga menerima dana Kanwil sebesar Rp. 25.000.000,00.

Kinerja Dukungan Publik (Public Support) yang kedua yaitu rasio ini menggunakan data Total Contribution/TC dan Total Expense (TE). Total

Gambar 4. Total Kontribusi Pemerintah dan Total Biaya BAZNAS Kab. Bengkalis (Dalam Milyar Rupiah)

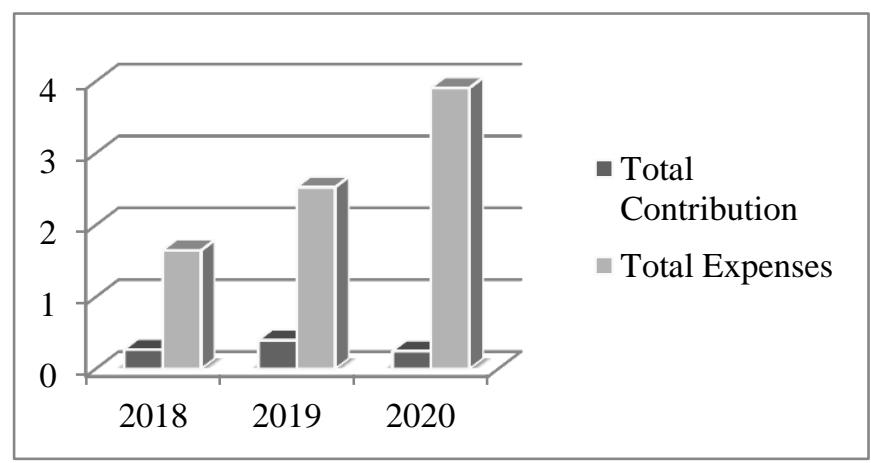

Sumber : Laporan Keuangan BAZNAS Kab. Bengkalis (2020)

Terlihat secara umum rasio ini menunjukkan kondisi penurunan. Walaupun demikian, rata-rata rasio ini berada di posisi angka 0,11 yakni dibawah 0,50 . Menurut teori, rasio dibawah nilai 0,50 ini menunjukkan bahwa pendapatan utama BAZNAS Kab. Bengkalis bergantung pada dukungan publik (masyarakat).

Secara umum rasio ini rata-rata berada di posisi angka 0,13 yakni dibawah atau kurang dari 1. Menurut teori, rasio

Contribution/TC tertinggi Tahun 2019. Namun hanya mampu menopang biaya penggunaan dana BAZNAS Kab. Bengkalis sebesar 16\% pada Tahun 2019. Sementara sisanya ditutupi dari penggunaan dana Zakat, Infak dan Sedekah yang berhasil dihimpun sendiri oleh BAZNAS Kab. Bengkalis. begitu pula secara umum fenomena yang terjadi di Tahun 2018 dan Tahun 2020.

.

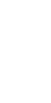

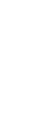




\section{Gambar 5. Total Biaya Penghimpunan Dana dan Total Pendapatan BAZNAS Kab. Bengkalis (dalam Milyar Rupiah)}

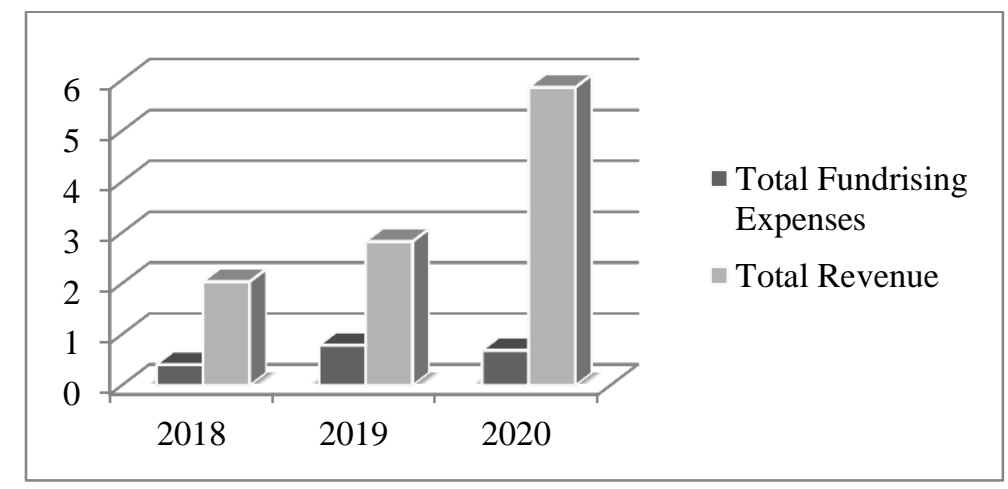

Sumber : Laporan Keuangan BAZNAS Kab. Bengkalis (2020)

Nilai rata-rata rasio ini berada di posisi angka 5,69 yakni diatas 1. Artinya setiap Rp1 biaya yang dikeluarkan untuk membiayai program penghimpunan dana menghasilkan pendapatan 5,69. Menurut teori, rasio Efisiensi Penghimpunan Dana (Fundrising Efficiency) diatas 1 ini menunjukkan bahwa total pendapatan lebih besar dari biaya penghimpunan dana.

\section{KESIMPULAN}

Rasio Fiscal Performance dengan perhitungan TR : TA $=3,76$. Rasio 3 diatas 1,0 menunjukkan Pendapatan/Perolehan Dana (Total Revenue) tahunan lebih besar dari Total Asset. Dan dengan perhitungan (TR-TE) : TA yang bernilai positif menunjukkan Pendapatan/Perolehan Dana (Total Revenue) lebih besar dari Biaya Perolehan Dana (Total Expenses), dan proporsi pendapatan dapat disimpan menjadi aset pada tahun yang bersangkutan. Rasio Public Support dengan perhitungan TC : TR $=0,11$. Rasio dibawah 0,50 menunjukkan Pendapatan/Perolehan Dana (Total Revenue) lembaga tidak bergantung pada Kontribusi Pemerintah dan Dana Sukarela (Total Contribution) melainkan bergantung pada sukungan Publik/Masyarakat (Public Support). Kemudian dengan perhitungan TC : $\mathrm{TE}=0,13$ menunjukkan lembaga tidak bergantung pada Kontribusi Pemerintah dan Dana Sukarela (Total Contribution) dalam menjalankan program (penyaluran dana kepada Mustahik) maupun untuk biaya operasional (Total Expenses). Rasio
Fundraising Efficiency dengan perhitungan (TR : FE) = 5,69 rasio diatas 1 menunjukkan Pendapatan/Perolehan Dana (Total Revenue) lebih besar dari Biaya Penghimpunan Dana (Fundraising Expense).

\section{DAFTAR PUSTAKA}

Al-Zuhaily, Wahbah. 1995. Zakat Kajian Berbagai Macam Mazhab. Remaja Rosdakarya. Bandung

Ardani, Rangga., Kosim, Abu., \& Yuniartie, Emylia. 2019. Analisis Kinerja Lembaga Amil Zakit Pada Badan Amil Zakat Nasional (BAZNAS) Kabupaten Ogan Hilir dengan Metode Indonesia Magnificence Zakat (IMZ). Jurnal Penelitian dan Pengembangan Akuntansi, 12(1), p. 19-32.

Azizah, Siti Nur. 2018. Efektivitas Kinerja Keuangan Badan Amil Zakat Nasional (BAZNAS) Pada Program Pentasharufan dana Zakat di BAZNAS Kota Yogyakarta. Islamic Economics Journal, 6(1), p. 91-112.

Hafidhuddin, Didin. 1998. Zakat dalam Perekonomian Modern. Gema Insani. Jakarta.

Leksono, Sonny. 2013. Penelitian Kualitatif Ilmu Ekonomi. Rajawali Pers. Jakarta

Nasrullah, M. 2010. Peranan Zakat Sebagai Pendorong Multiplier Ekonomi. Jurnal Hukum Islam, 8(1) p. 108-119. 
P. Harto, Prayogo., Anggraeni, Vivi Sufi., \& Bayinah, Ainur. 2018. Komparasi Kinerja Lembaga Amil Zakat. Jurnal Akuntansi dan Keuangan Islam, 6(1), p. 19-33.

Prasetyoningrum, Ari Kristin. 2015.

Pendekatan Balance Scorecard

Pada Lembaga Amil Zakat Di Masjid Agung Jawa Tengah. Economica: Jurnal Pemikiran Dan Penelitian Ekonomi Islam, 6(1), p. 1-36.

Qadir, Abdurrahman. 1998. Zakat dalam Dimensi Mahdhah dan Sosial. PT. Raja Grafindo Persada. Jakarta.

Qardhawi, Yusuf. 2010. Hukum Zakat Studi Komperatif mengenai Status dan Filsafat Zakat berdasarkan Qur'an dan Hadits. Lentera Antar Nusa. Jakarta.

Ritchie, William J., \& Kolodinsky, Robert W, 2013. Non Profit Organization Performance Measure : An Evaluation of new and Existing Financial Performance Measures. Non Profit Management \& Leadership, 13(4), p. 367-381.

Romantin, Maya., Bahri, Efri Syamsul., \& Lubis, Ahmad Tarmidzi. 2017 Analisis Kinerja Keuangan Lembaga Zakat (Studi Kasus : Badan Amil Zakat Nasional). Jurnal Perisai,1(2), p. 96-116.

Sakti, Ali. 2007. Analisis Teoritis Ekonomi Islam Jawaban Atas Kekacauan Ekonomi Modern. Paradigma \& AQSA Publishing. Jakarta.

Yuanita, Ines. 2016. Penilaian Kinerja Lembaga Amil Zakat dengan Pendekatan Indonesia Magnificence Zakat (IMZ). Skripsi. Program Studi S1 Akuntansi Fakultas Ekonomi Universitas Jember. 